\title{
RELASI MAKNA LEKSIKAL LIRIK LAGU KESENIAN RODAD SEKARWANGI BOYOLALI
}

\section{THE RELATION OF LEXICAL MEANING ON RODAD SEKARWANGI ART IN BOYOLALI}

\author{
Diah Iskafatmawati Saputri, Wihadi Admojo \\ Tadris Bahasa Indonesia, Institut Agama Islam Negeri Surakarta \\ Jalan Pandawa Pucangan Kartasura Sukoharjo. \\ Pos-el: iskaffadiah12@gmail.com
}

*)Naskah diterima: 19 Juli 2020; direvisi: 7 September 2021; disetujui: 22 Oktober 2021

\begin{abstract}
Abstrak
Penelitian ini membahas relasi makna leksikal lirik lagu pada kesenian Rodad Sekarwangi yang terletak di desa Kendelban, Kecamatan Kemusu Kabupaten Boyolali. Jenis penelitian yang digunakan adalah deskriptif kualitatif. Teori yang digunakan adalah teori relasi makna dari I Dewa Putu Wijana dan Josh Daniel Parera. Pengumpulan data diperoleh dari dokumentasi dan diperkuat dengan wawancara serta observasi. Analisis data dilakukan dengan (1) mengumpulkan data dari lirik lagu kesenian rodad, (2) melakukan klasifikasi dari data yang termasuk ke dalam bagian relasi makna leksikal, (3) menyajikan data dalam bentuk tabel dan analisis, kemudian (4) menyimpulkan temuan data. Hasil penelitian menunjukkan, dalam lirik lagu kesenian Rodad terdapat relasi makna leksikal berupa, antonimi 12 data, sinonimi 32 data makna denotasi sebanyak 72 data dan konotasi 13 data. Berdasarkan hasil penelitian disimpulkan bahwa makna denotatif lebih banyak digunakan dalam lirik lagu kesenian rodad Sekarwangi. Makna denotatif lebih komunikatif dan mudah dipahami sesuai dengan waktu, budaya, agama, kondisi bahasa dan tuturan masyarakat saat itu.
\end{abstract}

Kata kunci: semantik, relasi makna, rodad

\begin{abstract}
This study discusses the relation of the lexical meaning of song lyrics to the art of Rodad Sekarwangi which is located in the village of Kendelban, Kemusu district, Boyolali Regency. The type of research used is descriptive qualitative. The theory used is the theory relation of lexical meaning from I Dewa Putu Wijana and Josh Daniel Parera. Data collection was obtained from documentation and strengthened by interviews and observations. Data analysis was carried out by (1) collecting data from the lyrics of the Rodad art song, (2) classifying the data included in the lexical meaning relation section, (3) presenting the data in tabular form and analysis, then (4) concluding the data findings. The results showed that in the lyrics of the Rodad art song, there are lexical meaning relations in the form of 12 data antonyms, 32 synonyms, 72 data, denotative meaning data and 13 data connotations. Based on the results of the study, it was concluded that denotative meanings were mostly used in the lyrics of the Rodad Sekarwangi art song. The denotative meaning is more communicative and easy to understand according to the time, culture, religion, language conditions and speech of the people at that time.
\end{abstract}

Keywords: semantics, meaning relation, rodad 


\section{PENDAHULUAN}

Kesenian tradisional merupakan kesenian yang di ciptakan oleh masyarakat mengandung unsur keindahan dan hasilnya menjadi milik bersama (Liliweri, 2003: 1038). Kesenian daerah merupakan budaya khas yang berasal dari masyarakat serta diwariskan secara turun-temurun oleh masyarakat asli daerah tersebut.

Kebudayaan ini menjadi identitas asli dari daerah itu sendiri. Biasanya kesenian ini ditemukan dalam masyarakat sesuai dengan kondisi dan karakteristik kehidupan masyarakat setempat (Suhadi, 2019: 136). Salah satunya pada daerah agraris seperti desa Kendel, Kemusu, Boyolali.

Desa Kendelban, Kemusu, Boyolali memiliki budaya khas yang disebut dengan rodad. rodad merupakan kesenian yang memadukan fungsi agama, hiburan, dan rasa sosial dalam sebuah pementasan. Pada awalnya pementasan rodad ditujukan kepada masyarakat sebagai sarana menuntut ilmu. Ilmu-ilmu agama disisipkan melalui parikan dan tembang dari sang juru lagu (panggak) yang berasal dari karangan juru rodad. Tembang itu hadir sebagai salah satu media untuk syiar Islam terutama pada daerah pesisir pantai sebagai penerima ajaran Islam pertama kali, lalu mulai menyebar ke daerah lainnya.

Lirik lagu dalam tembang dan parikan yang dibawakan juru lagu menjadi objek penelitian mengenai makna. Semantik diartikan sebagai telaah makna. Makna tersebut berbentuk lambang atau tanda. Ia memiliki pengaruh dengan tuturan atau tulisan manusia dengan masyarakat (Tarigan, 1985:7).

Dalam makna, hubungan antarkomponen memiliki tingkatan tertentu. Pertama adalah bunyi, kemudin tata bahasa, terakhir tatanan bahasa mempunyai bentuk dan hubungan yang merefleksikan makna (Aminuddin, 1988:15). Bentuk lirik lagu berupa kata-kata yang ada pada pementasan rodad termasuk dari kategori mengenai cakupan semantik pada tingkat ketiga. Kemudian, dari makna-makna tersebut termasuk bagian dari relasi makna yang membentuk makna.

Berbeda objek dengan lirik lagu, Jusminti, Garing (2017) memaparkan analisisnya dengan judul Analisis Semantik Cerita Lakipadada membahas mengenai makna semantik dalam sebuah cerpen. Makna tersebut mencakup makna leksikal, gramatikal, makna kias dan pepatah.

Tidak hanya itu, makna dalam semantik juga dapat diketahui dengan tanda tertentu, seperti pada tesis Ulfiana, Elita (2015) dengan judul Satuan Ekspresi Pengungkap Aroma Pada Parfum membahas makna semantik leksikal khususnya makna konotasi dan makna denotasi dalam mengungkapkan satuan aroma pada parfum. Dari penelitian tersebut ditemukan satuan kebahasaan pengungkap aroma parfum, memaparkan ekspresi pengungkap aroma pada parfum, dan hubungan satuan ekspresi tersebut terhadap usia dan jenis kelamin pengguna. Dari kedua penelitian tersebut disimpulkan bahwa cakupan makna memiliki banyak artian. Bagaimanapun objeknya, makna memiliki artian sesuai dengan prespektif dan pengalaman penerjemah makna. Makna memiliki cakupan yang luas, tidak hanya pada cerpen, karya sastra tulis, dan aroma parfum. Makna juga bisa ditemukan pada lirik lagu kesenian daerah seperti Rodad.

Nuryani (2014: 56) mengatakan rodad adalah salah satu tradisi kesenian umat Islam. Kesenian ini berkembang seiring dengan tradisi memperingati hari besar Islam, seperti Maulid Nabi dan hari besar lainnya. Biasanya dalam pementasannya, menggunakan syair yang salah satu sumbernya berasal dari kitab Al-barjanzi, isi dari kitab tersebut adalah pujian kepada Rasulullah.

Latar belakang terbentuknya rodad, dalam penelitian Irawan (2018:52) menyebut- 
kan, rodad pada zaman dahulu digunakan sebagai sarana berdakwah. Kurangnya minat masyarakat dalam beribadah, dan semakin sedikit jamaah yang mengikuti kajian kerohanian, oleh karena itu, rodad dibentuk guna memberikan penyegaran terhadap syair Islam. Sehingga masyarakat kembali dekat dengan Allah.

Keterkaitan antara kesenian daerah dan makna dalam kasusastraan daerah bertujuan untuk menguak relasi yang tercipta, kebudayaan yang hadir membentuk kesenian yang dapat digali sejauh mana esensi yang diperoleh, serta memberikan penyegaran akademika dalam ranah semantik murni dengan kebudayaan daerah masyarakat setempat.

\section{LANDASAN TEORI}

\section{Semantik dan Relasi Leksikal}

Lerher (dalam Pateda, 2001:6) menyebutkan semantik adalah studi tentang kajian makna yang artiannya sangat luas. Hal itu disebabkan karena semantik menyinggung aspek-aspek struktur dan fungsi makna sehingga dapat dikaitkan dengan filsafat, psikologi dan antropologi. Parera (2004:9), membagi pembahasan makna menjadi dua bagian, yaitu makna leksikal dan makna gramatikal. Makna relasi leksikal dibahas mengenai hakikat makna, hubungan antarmakna, dan perkembangan antarmakna. Pada relasi gramatikal, terdapat makna dari segi pembentukan kata dan struktur kalimat. Makna leksikal (hubungan antarmakna) merupakan manifestasi pemikiran dalam bentuk persamaan, lawan kata, kecakupan makna, dan kejaminan makna.

Sejalan dengan hal tersebut, dalam pembahasan semantik leksikal khususnya pada pembahasan antarmakna, dalam pengertian tertentu disebutkan bahwa relasi leksikal adalah hubungan antarmakna dan kata. Dalam memahami makna baik leksikal maupun gramatikal dibutuhkan relasi makna untuk memperoleh makna dari kata atau frasa.

\section{Bentuk Relasi Leksikal}

Wijana (2015:48) menyebutkan delapan jenis relasi leksikal, di antaranya, medan makna, hiponimi, sinonimi, antonimi, kesejajaran dan kesalingan, konotasi dan denotasi, serta pengungkapan jumlah tak tentu.

Sinonim adalah kata yang menunjukkan persamaan makna (Wijana, 2015: 48). Kata yang bersinonim berfungsi sebagai pengganti makna kata jika dikaitkan dengan satuan kata tertentu, walaupun belum dapat menggantikan kata tersebut. Selaras dengan hal tersebut, sinonimi adalah sebuah akibat yang terjadi dari serapan antarbahasa, antardialek, antarragam bahasa (dalam Parera, 2004:63).

Perlawanan kata atau yang biasa kita sebut dengan antonimi merupakan kata yang berkontradiksi antara satu dengan lainnya. Pasangan yang diharapkan dalam antonimi adalah yang bermarkah dan tidak bermarkah lazimnya memiliki makna yang menyeluruh (Wijana, 2015: 48).

Antonimi adalah relasi keberbalikan antara dua buah kata yang bertentangan, berkebalikan dan kontras (dalam Chaer, 2007:132).

Parera (2004:98) mengatakan, hubungan antara makna konotasi dan denotasi terletak pada rujukan atau notasinya. Kata konotasi memiliki imbuhan ko- yang berarti "bersama dengan yang lain" dan denotasi memiliki imbuhan de-yang berarti "wajar" (sebagaimana adanya). Makna denotasi adalah makna yang telah disepakati oleh penutur bahasa (dalam Wijana 2015: 59). Makna denotasi dapat diartikan makna wajar (sesungguhnya), asli, diketahui mulainya, sesuai dengan kenyataannya. Makna konotasi adalah makna denotasi yang telah memperoleh tambahan perasaan tertentu, baik dari emosi ataupun nilai, maupun 
rangsangan yang tidak terduga dan bervariasi.

\section{METODE PENELITIAN}

Studi pustaka dengan menyertakan wawancara dengan pelaku kesenian merupakan jenis penelitian yang digunakan dalam penelitian ini. Studi pustaka dimaksudkan untuk menelaah teks yang berkaitan dengan lirik lagu rodad, sedangkan wawancara dilakukan untuk mendalami makna kesenian, serta menelisik lebih dalam mengenai lirik yang dituturkan. Sejalan dengan hal tersebut, penelitian ini akan dikaji dengan metode deskriptif kualitatif. Data dalam penelitian ini berupa teks dalam lirik lagu kesenian rodad yang ditranskripkan oleh Bapak Bukhori. Dari lirik tersebut, diambil frasa, klausa ataupun kalimat yang di dalamnya mengandung bentuk makna leksikal seperti: antonimi, hiponimi, medan makna, denotasi, konotasi, sinonimi, kesejajaran dan kesalingan, serta pengungkapan jumlah tak tentu.

Data sekunder berupa hasil wawancara dan hasil observasi yang telah dilakukan. Teknik analisis data yang digunakan adalah teknik analisis data lapangan model Miles dan Huberman. Miles dan Huberman (dalam Sugiyono, 2016:264) mengemukakan analisis data kualitatif dilakukan dengan cara interaktif (reduksi, data display, dan conclusion) dan berlangsung terus menerus sampai tuntas.

\section{HASIL DAN PEMBAHASAN}

Pembahasan dalam penelitian ini berupa pemaparan relasi makna leksikal lirik lagu kesenian rodad dan relevansinya dengan pembelajaran Bahasa Indonesia di SMP/ MTs. Pembahasan dalam penelitian ini sesuai dengan teori analisis lapangan Miles dan Huberman, pembahasan yang di paparkan, merupakan deskripsi data serta analisis.

\section{Sinonimi}

Sinonimi merupakan persamaan makna. Persamaan makna terjadi dari serapan antarbahasa. Fungsi dari sinonimi adalah mengganti makna kata jika dikaitkan degan makna lain. Setidaknya dari data sinonimi yang ditemukan, dominasi yang ditemukan adalah sinonimi yang disebabkan karena kolokasi dan dialek. Data yang ditemukan sebagai bentuk sinonimi adalah sebagai berikut.

\section{a. Sinonimi muncul karena kolokasi}

Kolokasi diartikan terbatas, artinya sinonimi muncul pada frasa yang memiliki kolokasi atau kata sanding. Data yang muncul adalah sebagai berikut.

Kembang kimpul suwal cekak kes nduwur dengkul (JJ 6.1)

Mudal madul bondomu entek bojomu ucul

(Kumpulan Pantun, 6.1)

Sinonimi yang ditemukan pada data (JJ 6.1) merupakan salah satu bentuk sinonimi antarfrasa, kata suwal cekak (celana pendek) dan nduwur dengkul (di atas lutut). Secara konotasi dua frasa tersebut memiliki arti sama pendek. Pada jenis ini dapat dimasukkan pada kategori sinonimi karena kolokasi antar dua frasa. Kolokasi yang ditemukan berupa suwal (n) + cekak (adj) dan nduwur (n) + dengkul (n).

Kulo nuwun ngaturiwu ninggo kang pinarak mriki

mugi-mugi panjenengan handedungo mring Hyang Widhi les ta tuning ndadi

(B 1.2) agami Islam namu kang kito rungkepi madlingul ulum pinaringan widodo halestari

(Kulo Nuwun, 1.2)

Data terakhir dari jenis sinonimi ini dalam lagu Kulo Nuwun (B 1.2), pada 
frasa Hyang Widhi. Hyang Widhi erat kaitannya dengan penyebutan Sang Pencipta pada agama Hindu. Hyang Widhi memiliki makna Tuhan sebagai kuasa atas seluruh pengetahuan di jagat raya ini. Dalam konteksnya, bisa dijabarkan lagi bahwa pengetahuan disetarakan dengan cahaya atau petunjuk bagi semesta, serta sebuah sebutan yang mulia dalam menyebut sifat Tuhan.

b. Sinonimi muncul antara bahasa umum dan dialek

Sinonimi ini biasa muncul akibat penyebutan yang masih terpengaruh dengan bahasa asal. Seperti dalam tabel berikut

Tabel 4.10 Sinonimi Bahasa Umum dan Dialek

\begin{tabular}{llll}
\hline Dialek & & Kata umum \\
\hline A 3.3 & mengramai & meramaikan & \\
\hline D 1.4 & pamirso & pemirsa & \\
\hline Q 1.1 & turatur & Q 1.2 & bilang \\
\hline Y 1.1 & nyakot & Y 1.3 & makan \\
\hline D 1.3 & kulo & C 1.2 & saya \\
\hline JJ 3.2 & srutu & M 1.2 & rokok \\
\hline B 1.1 & pinarak & CC 1.3 & duduk \\
\hline
\end{tabular}

Sinonimi yang terdapat pada tabel di atas memaparkan campuran antara bahasa Indonesia dan bahasa daerah yang digunakan dalam lirik lagu kesenian rodad. Rincian lagu dalam tabel tersebut di antaranya: Ambil Batu (BB), Kulo Nuwun (B), Kumpulan Parikan (JJ), Lukar Baju (M), Selamat Datang (C), Kulo Nuwun (D), EncekEncek Turatur Banjar Tono (Q), Tanjung Kratos (Y). Kata pamirso (pemirsa dalam bahasa Indonesia) dan mengramai (meramaikan). Bentuk sinonimi yang ditemukan selanjutnya berada pada data (CC 1.3) pada kata duduk dan data (B 1.1) pada kata pinarak, (JJ 3.2) pada kata rokok dan (M 1.2) pada kata srutu, (C 1.2) pada kata saya dan (D 1.3) pada kata kulo, (Y 1.1) pada kata nyakot dan (Y 1.3) pada kata makan, (Q 1.1) pada kata turatur dan (Q1.2) pada kata bilang. Makna yang terdapat pada data di atas memiliki makna yang sama. Bedanya terletak pada bahasa krama dan ngoko dalam bahasa Jawa.

\section{c. Sinonimi muncul untuk kerahasiaan}

Sinonimi yang ditemukan pada poin ketiga adalah sinonimi yang muncul untuk kerahasiaan. Kerahasiaan yang dimaksudkan adalah sebuah kata yang memiliki isyarat makna atau tanda. Tanda tersebut hanya dimiliki oleh geng tertentu, instansi tertentu, ataupun profesi tertentu. Sinonimi yang disebabkan untuk kerahasiaan ditemukan pada data
Banyak banyak sekali
Banyak banyak sekali
kami tidak mungkur pada pangeran kami (FF
1.3)
(Banyak-Banyak Sekali, 1.3)

Pada data (FF 1.3), dalam lagu Banyak Banyak Sekali (FF) ditemukan makna pangeran. Pangeran bermakna sebagai Sang Penguasa yang berarti Allah Swt. Penyebutan tersebut hanya dimengerti oleh masyarakat daerah Jawa. Masyarakat daerah lain belum tentu memahami penyebutan tersebut. 
Kupu kuning kupu kuning menconk neng lemah

tinimbang ngamping melbuo ngomah (JJ 2.2)

Kemudian data kedua ditemukan dalam lagu Kumpulan Parikan (JJ 2.2) pada kata ngamping. Ia memiliki sinonimi dengan kata berdiri di depan pintu. Bahasa ini lazim digunakan masyarakat Jawa, khususnya di daerah Kendel, Kemusu Boyolali.

lancur putih turune ono tratapan (JJ 7.1)

Cigrak-cigrak nganten anyar ngajak gojek

Waloh bakor dambatane pring selonjor

Miyar miyur nganten anyar ngajak awor

(Kumpulan Parikan, 7.1)

Data ketiga adalah data dengan identitas JJ 7.1 pada frasa lancur putih. Sebagian orang mungkin tidak memahami makna tersebut. Dalam bahasa Jawa lancur putih merupakan persamaan makna dari ayam jago berwarna putih.

Sinonimi atau persamaan makna yang ditemukan terbagi menjadi tiga sebab, yakni sinonimi sebagai kolokasi, sinonimi yang terjadi antara bahasa umum dan dialek atau lebih pada sinonimi antar bahasa, serta sinonimi yang muncul karena kerahasiaan.

\section{Makna Konotasi}

Makna konotasi adalah makna emotif yang dapat dibangkitkan melalui kata. Makna konotasi dapat disimpulkan sebagai makna denotasi yang telah memperoleh tambahan perasaan tertentu baik dari segi emosi nilai maupun rangsangan lainnya. Seperti data berikut

Inilah malam saya mau main

Main disini orang lihat muda-muda

Inilah sutro sutrolah ijo
Sutrolah ijo... sutrolah ijo berlapis-lapis (K 1.4

(Inilah Malem, 1.4)

Data (K.1.4) dengan lagu Inilah Malem (K) merupakan frasa sutrolah ijo atau dalam bahasa Indonesia diartikan kain sutra berwarna hijau. Kain yang dimaksudkan tidak hanya sekadar kain, akan tetapi sutra hijau merupakan sebutan bendera dari rodad. Bendera itu memiliki panjang tongkat kurang lebih $100 \mathrm{~cm}$ dengan bendera berwarna hijau sebanyak dua lapis. Bendera memiliki arti lambang dalam perkumpulan atau identitas dari Rodad Sekarwangi, pemilihan warna hijau tidak menutup kemungkinan diselaraskan dengan warna bendera Nahdatul Ulama, karena sebagian besar dari masyarakat desa menganut NU sebagai aliran kepercayaan mereka.

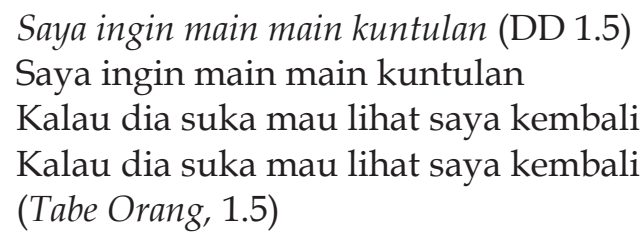

Pada data (DD 1.5) dengan kutipan saya ingin main main kuntulan. Sebenarnya, kata kuntulan dalam lagu Tabe Orang (DD) memiliki kata dasar kuntul, yang merupakan nama salah satu bangau atau sejenis burung pemakan katak. Kata kuntul diberi sufiks -an (kuntul + an) berubah menjadi kuntulan dengan pergantian fungsi yang menyatakan menyerupai atau meniru burung kuntul. Gerakan burung tersebut memiliki persamaan dengan gerakan pemain rodad. Oleh karena itu, secara tidak langsung lirik tersebut memiliki makna pemain ingin bermain rodad, yang tariannya seperti burung kuntul.

Konotasi merupakan makna kata yang kias atau tidak sama dengan yang lain, dalam lirik lagu rodad, konotasi difungsikan sebagai kalimat untuk mengungkapkan permainan dalam lirik baju itu bermain-main, 
sindiran kepada masyarakat dan petinggi daerah dengan liik kita syukur, jalan dimakan, serta identitas keagamaan yang ditunjukkan dengan lirik Sutrolah ijo... sutrolah ijo berlapis-lapis.

\section{Makna Denotasi}

Makna denotasi adalah makna sebagaimana adanya. Artian dalam makna denotasi sudah disepakati oleh para bahasawan. Denotasi berarti makna sesuai fakta. Data yang ditemukan dalam syair sebagai berikut

\footnotetext{
Anak ayam turun sepuluh Mati satu tinggal sembilan Bangun pagi sembahyang subuh (W 3.3) Minta ampun kepada Tuhan (Terang Bulan, 3.3)
}

Temuan (W 3.3), merupakan kalimat yang mengandung makna denotasi. Kalimat Bangun pagi sembahyang subuh dalam lagu Terang Bulan (W) memiliki makna yang sama dengan makna tertera. Kalimat tersebut merupakan kalimat nasihat untuk bangun pagi kemudian menjalankah sembahyang (salat) subuh, pada baris selanjutnya dalam data ini paparkan kalimat minta ampun kepada Tuhan, sehingga makna tersebut benar sebagaimana adanya.

\footnotetext{
Ikan cucut ada di laut

Ikan cucut ada di laut

Sekarang ombak bergoyang buntut

Andeng andeng di atas mulut (GG 2.4)

Andeng andeng di atas mulut

Jangan mandeng mundak kepencut

(Encek Emas, 2.4)
}

Temuan selanjutnya yakni (GG 2.4) Andeng-andeng di atas mulut. Andeng-andeng (Jawa) merupakan kata lain dari tahi lalat. Fungsi dari kalimat ini sebagai parikan atau sampiran untuk menunjukkan makna setelahnya dalam lagu Encek Emas (GG).
Makna denotasi yang ditemukan dalam data diatas, memiliki fungsi sebagai deskripsi kehidupan masyarakat karena dalam data tersebut menjelaskan kehidupan masyarakat Islam sehari-hari, seperti sembahyang subuh, penyebutan ciri fisik andeng-andeng, dan denotasi juga memiliki fungsi sebagai kalimat penjelas.

\section{Antonimi}

Antonimi merupakan lawan kata atau makna yang berkontradiksi antara satu kata dengan kata lainnya. Dua buah kata yang kontrer, kontra, dan bertentangan. Ditemukan tiga jenis antonimi dalam lirik lagu kesenian rodad. Di antaranya jenis kontradiksi dan berbalasan seperti dalam temuan data berikut

\section{a) Kontradiksi}

\author{
Assalamualaikum \\ Assalamualaikum \\ Kepada bapak-bapakku kita terimakasih \\ kepadanya \\ Selam at datang selamat pergi \\ Pada bapakku yang datang dan kembali (A \\ 2.5) \\ Dan kepandaian mana yang suci \\ Muga-muga jangan sampai lupa \\ (Assalamualaikum, 2.5)
}

Pada data (A 2.5), dalam baris kalimat Pada bapakku yang datang dan kembali merupakan antonimi dengan tipe kontradiksi. Leksem yang digunakan menggunakan kata datang dan kembali, keduanya saling berbalik dan menolak satu sama lain. Selaras dengan hal tersebut, pada data A 2.4 kata datang dan pergi juga memiliki sifat menolak antara satu dengan yang lain, kurang lebih makna pada kedua data ini sama sehingga terdapat dua buah temuan dalam lagu

Assalamualaikum (A).

Kembang lombok sedhompol mlegok e sithok 
mesem mlorok mbedah pager ngelungke

rokok (JJ 3.2)

(Kumpulan Parikan, 3.2)

Data selanjutnya yakni (JJ 3.2) pada kata mesem mlorok. Kata tersebut memiliki arti yang sangat menyimpang satu dengan lainnya mesem 'senyum' dan mlorok 'melotot'. Secara makna, tersenyum memiliki arti positif seperti ramah, baik, bahagia. melotot diartikan dengan negatif karena menunjukkan sifat marah, keras, dan terkesan angkuh.

\section{Banyak banyak sekali \\ Banyak banyak sekali \\ kami tidak mungkur dengan pangeran saya \\ (FF.3.3) \\ (Banyak Banyak Sekali, 3.3)}

Kemudian data FF 3.3 pada frasa tidak mungkur diasumsikan bahwa terdapat bentuk antonimi dari taat. Salah satu ciri dari tipe kontradiksi lebih pada adanya kata negasi atau sangkalan seperti kata tidak dalam data lagu Banyak Banyak Sekali (FF) di atas.

Enek seng abang abang mileh seng ireng Enek seng ireng-ireng gampang jahitane Enek seng padhang-padhang milih seng petheng (JJ 5.3)

Yen petheng petheng gampang jiwitane

(Kumpulan Parikan, 5.3)

Pada data ketiga dengan kode (JJ 5.3), merupakan antonimi dengan tipe kontradiksi, seperti pada data pertama. Kalimat Enek seng padhang, mileh seng petheng artinya ada yang terang tetapi memilih yang gelap. Dua kata tersebut saling menolak dan bersifat negasi (sangkalan)

\section{b) Berbalasan}

Karanggatak lore Penggung ngidul sithik terusane Gadelan wong urung nembung wes cemepak kui bagiane dagelan (JJ 11.3)
Data (JJ 11.3) dengan bunyi Wong urung nembung wes cemepak iku bagiane dagelan dalam bahasa Indonesia artinya belum meminta, tetapi sudah diberi itu bagiannya pelawak. merupakan tipe antonimi komplementer yang menuntut balasan sesuai dengan konteks. Kata urung nembung (belum bilang) kemudian disusul dengan wes cemepak (sudah disiapkan ) merupakan antonimi yang berbalasan.

\section{iki kasur yo di lempit yo dilempit malah dibuka (JJ 11.1) \\ Anak busur njaluk duit ora dikei malah dikeplak \\ (Kumpulan Parikan, 11.1)}

Ditemukan data (JJ 11.1) pada kata dilempit dan dibuka. Kata dasar lempit (lipat) dan buka dalam konotasinya membuka lipatan adalah tipe antonimi berbalasan atau realisional. Makna yang terkandung dalam baris tersebut ditemukan penyair menggunakan lirik kalimat tersebut sebagai sampiran dan bentuk antonimi dari kasur yang sudah dirapikan malah dibuka kembali. Dari data di atas, antonimi memiliki fungsi sebagai penjelas sampiran dan penanda emotif sisi positif dan negatif. Tipe antonimi yang ditemukan adalah berbalasan dan kontradiksi.

\section{PENUTUP}

Hasil penelitian menunjukkan, dalam lirik lagu kesenian rodad terdapat relasi makna leksikal berupa, antonimi 12 data yang memiliki fungsi sebagai penjelas sampiran dan penanda emotif sisi positif dan negatif. Tipe antonimi yang ditemukan adalah berbalasan dan kontradiksi. sinonimi 32 data yang terbagi menjadi tiga sebab, yakni sinonimi sebagai kolokasi, sinonimi yang terjadi antara bahasa umum dan dialek atau lebih pada sinonimi antarbahasa, serta sinonimi yang muncul karena kerahasiaan. makna denotasi sebanyak 72 data dan konotasi 13 data. Temuan yang 
paling banyak adalah makna denotasi dengan jumlah 72 data, sedangkan presentase paling kecil ditemukan pada konotasi sebanyak 13 data. Berdasarkan hasil penelitian disimpulkan bahwa makna denotatif lebih banyak digunakan dalam lirik lagu kesenian rodad Sekarwangi. Makna denotatif lebih komunikatif dan mudah dipahami sesuai dengan waktu, budaya, agama, kondisi bahasa dan tuturan masyarakat saat itu.

\section{DAFTAR PUSTAKA}

Aminuddin.1988. Semantik: Pengantar Studi Tentang Makna. Bandung: Sinar Baru Offset.

Chaer, Abdul. 2007. Leksikologi dan Leksikografi Indonesia. Jakarta: PT Rinneka Cipta.

Garing, Jusmiyanti. 2017. “Analisis Semantik Cerita Lakipapa". Jurnal Sawerigading. Vol 23, No 1, Juni 2017. Hal 115124.

Irawan, Dimas. 2018. Nilai-Nilai Pendidikan Islam dalam Kesenian Rodat AlFajar di Dukuh Kiringan, Cenden, Sambi, Kabupaten Boyolali Tahun 2018. Skripsi, IAIN Surakarta.
Liliweri, Alo. 2003. Makna Budaya dalam Komunikasi antar Budaya. LKIS Yogyakarta.

Pateda, Mansoer. 2001. Semantik Leksikal. Jakarta: PT Rineka Cipta.

Parera, Josh Daniel. 2004. Teori Semantik Edisi Kedua. Jakarta: Erlangga .

Suhadi. 2019. "Pelestarian Kebudayaan Daerah melalui Kesenian Tradisional Dodod di Kampung Pematang Desa Mekarwangi Kecamatan Saketi Kabupaten Pandeglang". Jurnal Dinamika. Vol 6, No.4, Desember 2019.

Tarigan, Henry Guntur.1985. Pengajaran Semantik. Bandung: Angkasa.

Ulfah, Nuryani. 2015. Nilai-Nilai Pendidikan Islam Pada Kesenian Tradisional Rodat di Desa Sidomukti Kecamatan Bandungan Kabupaten Semarang Tahun 2014. Skripsi: IAIN Salatiga.

Ulfiana, Elita. 2015. Satuan Ekspresi Pengungkap Aroma Pada Parfum. Tesis: Universitas Gadjah Mada.

Wijana, I Dewa Putu. 2015. Pengantar Semantik Bahasa Indonesia.Yogyakarta: Pustaka Pelajar. 